\title{
Challenges of Water Crisis on Women's Socio-Economic Activities in the Buea Municipality, Cameroon
}

\author{
Lotsmart N. Fonjong $^{1} \&$ Martha Abongwa Ngekwi ${ }^{2}$ \\ ${ }^{1}$ Faculty of Social and Management Sciences University of Buea, Cameroon \\ ${ }^{2}$ Department of Women and Gender Studies, University of Buea, Cameroon \\ Correspondence: Lotsmart Fonjong, Faculty of Social and Management Sciences, University of Buea, PO Box \\ 63, Buea, Cameroon. Tel: 237-677-513-620. E-mail: flotsmart@gmail.com
}

\author{
Received: April 17, 2014 Accepted: October 17, 2014 Online Published: November 18, 2014 \\ doi:10.5539/jgg.v6n4p122 URL: http://dx.doi.org/10.5539/jgg.v6n4p122
}

\begin{abstract}
Although water is a basic human right, it is also essential for achieving sustainable development and poverty alleviation. The economic cost of water crisis can be very severe for women in low income societies whose activities revolve around water, ranging from domestic to economic needs. This paper looks at the water situation of a rapidly growing town, Buea, in the SW Region of Cameroon, and how it poses a challenge to women's socio-economic efforts. The results presented are based on analysis of field data collected from 177 water users and stakeholders of the study area through a stratified random sampling technique and analyzed with the help of SPSS and Epi softwares. Findings reveal that the water crisis in Buea is human- induced and women are the most affected because their socioeconomic lives are highly dependent on water. While this situation directly affects the quality/quantity of water, and the amount of time women spend on water collection, it also has far-reaching implications on the socio-economic welfare of the municipality.
\end{abstract}

Keywords: economic activities, water crisis, women

\section{Introduction}

There is widespread recognition that the world is facing a growing water crisis, affecting the wellbeing of millions of the poorest people. Rapidly growing populations, urbanization, agricultural intensification and climate change, all contribute to greater competition and scarcity of water resources (UN, 2005). In Cameroon, the water situation remains very difficult, particularly in the two major cities of Douala and Yaounde and other fast growing towns like Buea. The creation of a state university in Buea in 1993 completely changed the pace of urbanization and population, versus resource ratio of Buea. Water and other basic social infrastructures have continuously fallen short of popular demand, thus placing the municipality among crisis-ridden areas in Cameroon. - It is commonplace to see major neighbourhoods like Bokwoango, Buea town, Molyko and Bomaka - going for weeks unend without potable water or running taps.

The water situation of Buea has reached crisis level; the solution requiring the expansion of existing water infrastructures and supply networks. Unfortunately, the expansion does not seem to be the priority of the municipal authorities and/or government. This lack of public interest in the water situation in Buea (as is the case with other municipalities) is not unrelated to the fact that the urban poor and other vulnerable groups who bear the brunt of the crisis are not those in decision-making circles. A male dominated public and community water management sector does not see the urgency to address the water crisis partly because they cannot directly identify themselves with the difficulties of women--the primary users. These women have varied needs for water, daily, including domestic use, crop production and commercial activities. This therefore puts women in a more disadvantaged position when water is scarce or when there are disruptions in the supply systems in urban areas (Chipeta, 2009). It is in this regard that Tamasang (2007) asserts that access to potable water remains a nightmare to rural populations and marginalized urban populations in Cameroon, with women and children bearing the burden.

Buea is the capital of the South West Region, one of the ten administrative regions of Cameroon. It was also the first capital of German colonial Cameroon, which until the creation of a state University in 1993, was disadvantaged in terms of infrastructure and economic growth, relative to the other nine regional capitals. The 
municipality has thus relied on the facilities left behind by colonial administrations, with very little maintenance and upgrading, especially water infrastructures. Buea is physically well watered, -albeit without regular supply of water. Ironically, there are about thirteen water catchments, including streams and sufficient rain water, yet potable water - remains an issue.

CAMWATER, which is the sole commercial water provider in the town is unreliable, expensive and does not cover the entirety of the Municipality. Its network connections cover mostly localities along the major highway from Buea Town through Bokwaongo and south or lower Buea to Mile 17 (see Map 1). This leaves the neighborhoods that are about $600 \mathrm{~m}$ and beyond, off the major highway without pipe-borne water. Getting private water connections from CAMWATER to these neighborhoods is very expensive (a single connection can cost more than 2000 USD in Bomaka). Urbanisation has made natural sources of water such as springs and rivers - like the Ndongo River that runs across $75 \%$ of the town--no longer safe. Inhabitants (especially the poor) of Buea have resorted to doubtful sources of water that have sometimes led to cholera outbreaks. Women and children travel long distances to search for potable water from the few available public taps, usually overcrowded with people scrambling for water. Everyone is directly or indirectly effected by the water crisis; students, small business owners, schools and hospitals. The water situation of the town is affecting particularly women and girls, with a far reaching impact on the growth and socio-economic development of the municipality.

Providing physically accessible clean water is essential to enable women and girls achieve sustainable development (UN, 2005:3). Women's high demand for water (Aureli \& Brelet, 2004) could bring change and make a difference through their participation in decision-making bodies on water related issues. This cannot however be achieved if the main users of water are sidelined from the management and development of this valuable natural resource in Cameroon. Here, the rising demand for access to water has transformed this basic need to a "luxury," with only a few having access to it. Rapid urbanization has stimulated this high demand for water in a context where there is no corresponding increase in the development of existing water infrastructures. The water crisis has critical implications for people's lives and livelihoods as well as for overall economic development and social prosperity of affected populations, particularly women.

Water scarcity has caused many city dwellers to resort to various water sources of doubtful quality with obvious health concerns, especially for women. It is therefore evident that water sustainability does not only rely on its availability, but on its exploitation and management, to attain sustainable socio-economic progress. It is within this background of the indispensability of water to human survival that this study analyses the question and implication of water crisis on women's socioeconomic activities in Buea. In concrete terms, how does the present situation of water in Buea play on women's activities?

\section{Methodology}

Buea Municipality, where the study has been carried out, was the first colonial capital of Cameroon under German rule from 1901-1909. After independence, Buea served as the capital of West Cameroon in the Federal Republic of Cameroon from 1961 to 1972 and is currently the headquarters of the South West Region. Until the creation of the state University of Buea in 1993, the Municipality was dominantly rural with few migrants who were civil servants. The population was 90,088 inhabitants according the last Cameroon National Census of 2005, and depended on colonial infrastructures (health and educational services, including water supply) which were largely adequate. This dynamics changed with the creation of the University of Buea as the population more than doubled from 32,871 inhabitants in 1987 to 90,088 inhabitants in 2005 (National Institute of Statistics Cameroon); far above the carrying capacity of the available infrastructures, water supply being one of the most important social amenities.

The research is descriptive, with primary data obtained from field observations and semi- structured interviews. Field observations and interviews were instrumental to assess the various uses of water by the local people, understand the economic uses of and the conditions of water sources in the study area. Sites visited in this light included water sources (taps, springs, and streams) and services that make use of the water (restaurants, hospitals, and roadside vendors). We conducted semi-structured interviews with ten individuals from water management institutions, chiefs and water committee members. The stratified random sampling technique was applied to get a representative sample of the neighborhoods of the town and a random sampling technique to select the study population. The neighborhoods studied included Bokwaongo, Great-Soppo, Bonduma, Molyko, Buea Town and Bwitingi, which are also areas of severe water crisis. The choice of these neighborhoods is guided by the availability of springs, streams and public stand taps within them as well as areas without these water sources to evaluate the intensity of water crisis.

A total of 167 participants were selected from the six neighborhoods, both for the survey and focus group 
discussions. This sample generally consists of the active population with a mean age of 40 and the mode for marital status is married. The majority $(86 \%)$ of the respondents are women, most of whom combine both informal sector activities and their traditional reproductive roles, which depend on a regular supply of water. The few men (14\%) who participated in the study were recruited because of their administrative roles in water management and their status as traditional leaders of the various neighborhoods. The statuses of these men give them access to important information that either corroborates the stories of the women or enriches the study. The data has been analyzed with the help of SPSS and Epi softwares, and the results presented using simple descriptive statistics.

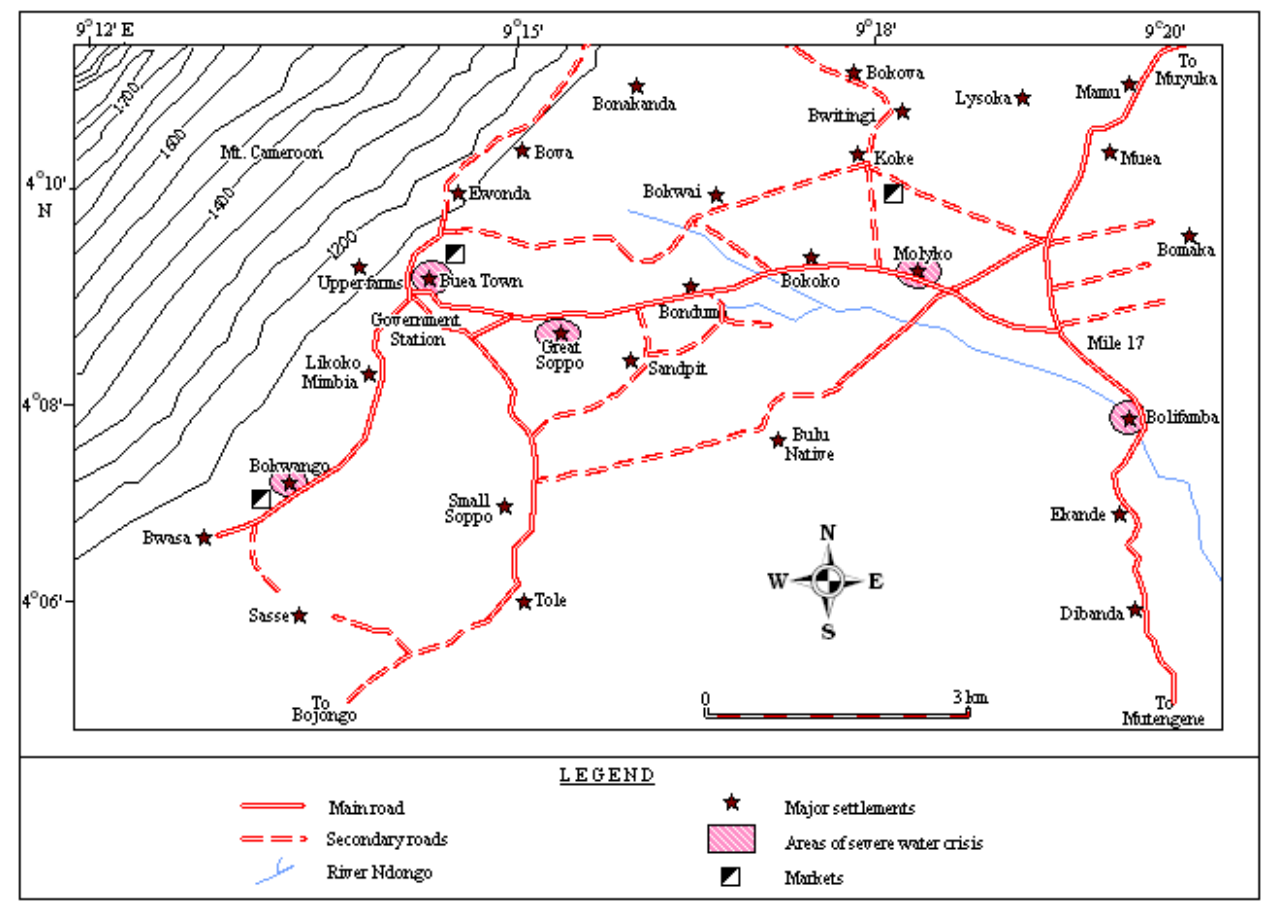

Figure 1. Studied localities within the Buea Municpality

Source: Adapted from national institute of cartography (N.I.C) (2008).

\subsection{Women Have a High Demand for Water Because of the Activities they perform}

Women use water more--for cleaning the house, washing of clothes and plates, cooking and commercial purposes--than men, while fishing emerges as the least activity requiring potable water. It is accounted that $45.1 \%$ women use water very often for washing of clothes/plates as opposed to just $1.0 \%$ for men, while $44.4 \%$ women consume water very often for house cleaning, as opposed to $0.8 \%$ for men. Respondents reported that women use water for cooking corresponding to $44.2 \%$ as against $5.4 \%$ for men. Furthermore, $37 \%$ indicated that women take up water for maternal care as opposed to zero percent for men. $38 \%$ of respondents observed that women use water very often for commercial purposes and $10.9 \%$ indicated that men take up water very often to cater for animals contrary to $5.4 \%$ for women. Although fishing is not a major economic activity in Buea, some $17.5 \%$ of respondents specified that men use water very often for fishing contrary to $1.6 \%$ for women. The findings indicate that it is only in fishing and animal rearing that men's demand for water exceeds that of women. As indicated in Table 1, women's high demand for water in Buea suggests that these women need to be empowered to participate in water management in order to ensure water sustainability and the socio-economic development in the area.

Table 1. Frequency of water usage by activity and by sex

\begin{tabular}{llllllll}
\hline Uses & Actors & $\begin{array}{l}\text { Never } \\
\%\end{array}$ & $\begin{array}{l}\text { Very } \\
\text { rarely } \%\end{array}$ & $\begin{array}{l}\text { Rarely } \\
\%\end{array}$ & $\begin{array}{l}\text { Often } \\
\%\end{array}$ & $\begin{array}{l}\text { Very often } \\
\%\end{array}$ & $\begin{array}{l}\text { Count } \\
\text { (MRA) } \\
\%\end{array}$ \\
\hline Washing & of & Men & 0.0 & 2.9 & 3.3 & 2.8 & 1.0 \\
\hline
\end{tabular}




\begin{tabular}{|c|c|c|c|c|c|c|c|}
\hline cloths/plates & Women & 0.0 & 0.0 & 0.0 & 44.9 & 45.1 & 90 \\
\hline \multirow{2}{*}{$\begin{array}{l}\text { Cleaning of the } \\
\text { house }\end{array}$} & Men & 0.8 & 0.0 & 0.8 & 4.0 & 0.8 & 6.4 \\
\hline & Women & 0.0 & 0.0 & 0.0 & 49.2 & 44.4 & 93.6 \\
\hline \multirow{2}{*}{ Cooking } & Men & 0.0 & 0.0 & 3.1 & 6.2 & 5.4 & 14.7 \\
\hline & Women & 0.0 & 0.0 & 0.0 & 41.1 & 44.2 & 85.2 \\
\hline \multirow[t]{2}{*}{ Gardening/farming } & Men & 0.0 & 0.0 & 1.9 & 11.3 & 0.9 & 14.1 \\
\hline & Women & 0.0 & 0.0 & 3.8 & 54.7 & 27.4 & 85.9 \\
\hline \multirow[t]{2}{*}{ Fishing } & Men & 0.0 & 0.0 & 3.4 & 36.8 & 17.5 & 57.7 \\
\hline & Women & 6.7 & 0.0 & 16.9 & 17.1 & 1.6 & 42.3 \\
\hline \multirow[t]{2}{*}{ Cater for animals } & Men & 0.0 & 0.0 & 1.1 & 30.4 & 10.9 & 42.4 \\
\hline & Women & 2.2 & 0.0 & 6.5 & 43.5 & 5.4 & 57.6 \\
\hline \multirow{2}{*}{$\begin{array}{l}\text { Commercial } \\
\text { purposes }\end{array}$} & Men & 0.0 & 0.0 & 1.5 & 15.9 & 0.0 & 17.4 \\
\hline & Women & 3.8 & 1.5 & 3.0 & 36.4 & 37.9 & 82.6 \\
\hline \multirow{2}{*}{ Sell } & Men & 1.1 & 0.0 & 2.1 & 7.4 & 3.4 & 14 \\
\hline & Women & 7.0 & 0.0 & 5.3 & 57.9 & 15.8 & 86 \\
\hline \multirow[t]{2}{*}{ Care for the sick } & Men & 6.8 & 8.5 & 1.7 & 0.0 & 0.0 & 17 \\
\hline & Women & 1.7 & 0.0 & 0.0 & 53.1 & 28.2 & 83 \\
\hline \multirow[t]{2}{*}{ Maternal care } & Men & 8.4 & 0.0 & 0.0 & 3.4 & 0.0 & 11.8 \\
\hline & Women & 2.5 & 0.0 & 0.0 & 47.9 & 37.8 & 88.2 \\
\hline
\end{tabular}

Source: field work (2013).

Traditionally, women in Buea are responsible for household activities such as cooking, washing, and fetching water for domestic and commercial purposes (Epule et al., 2011) which demand a lot of water. Owing to the current demand and mounting competition for the limited water from divers sectors like power generation, industry and agriculture, it has become very difficult for the poor and particularly women to access this scarce resource for production, consumption and other social uses. This is limiting to women's socio-economic activities and their contribution to the local economy. A positive change that enhances women's economic productivity in the municipality will depend on the extent to which women's practical and strategic gender needs are mainstreamed into water policies and projects.

\subsection{The Water Crisis in Buea Municipality is Human-Made and Not Naturally Induced}

The general demand for water far exceeds its supply, creating water scarcity which is mostly felt by the poor. Inadequate water supply is not uniformly observed in the municipality as there is regular supply of water within other neighborhoods like the Government Residential Areas (GRA) and Federal Quarters inhabited by those of high income and social strata. This reinforces the point that spatial disparity associated with distribution and consumption of water from institutional or private water schemes within Buea is a function of the capacity of water infrastructures and management. In fact, these two factors explain why despite its geographic location along the equator where Buea receives a great amount of rainfall and possess a solid hydrographic network, access to water remains an enormous problem (Yongsi, 2010).

Bokwaongo is the neighborhood with the worst water situation in Buea and Bwitingi has the relatively best water supply conditions. In Bokwaongo, respondents attributed the situation to the absence of natural springs and unreliable supply from CAMWATER, to the extent that they can sometimes go for months without water. Table 2 presents respondents' general evaluation of the state of water supply in their neighborhoods. The mean results show that $28.5 \%$ of neighborhoods have inadequate water supply, $33.9 \%$ have fair water distribution, $18.2 \%$ experience water rationing, $8.3 \%$ suffered from low water pressure, while $11 \%$ have no water at all. Neighborhoods on the whole that suffer from poor water supply are new residential areas, which do not have water catchments and supply from CAMWATER. It is also worth noting that $33.9 \%$ who reported a fair water distribution are either dependent on natural springs or live within the high-class residential areas, notably the Synod Office and Governor's residential areas.

Table 2. Situation of water availability according to locality

\begin{tabular}{llllllll}
\hline Locality & Inadequate & Fair water & Rationing of & Low water & No & Total No & Total \\
& water supply & distribution & water supply & pressure & portable & Of & $\%$ \\
\hline
\end{tabular}




\begin{tabular}{llllllll}
\hline & $\%$ & $\%$ & $\%$ & $\%$ & $\begin{array}{l}\text { water } \\
\%\end{array}$ & $\begin{array}{l}\text { respondents } \\
(131)\end{array}$ \\
\hline Bokwaongo & 50 & 0.0 & 30 & 10 & 10 & 10 & 7.6 \\
Mile 16 & 0.0 & 100 & 0.0 & 0.0 & 0.0 & 15 & 9.9 \\
Bonduma & 30.3 & 19.7 & 50 & 0.0 & 0.0 & 15 & 7.6 \\
Buea Town & 50 & 0.0 & 25 & 25 & 0.0 & 10 & 11.5 \\
Bwitingi & 0.0 & 100 & 0.0 & 0.0 & 0.0 & 15 & 11.5 \\
Great & 50.8 & 24.6 & 24.6 & 0.0 & 0.0 & 15 & 11.5 \\
Soppo & & & & & & & \\
Molyko & 50.5 & 0.0 & 33.1 & 16.4 & 0.0 & 15 & 11.5 \\
Muea & 33.3 & 41.7 & 0.0 & 25 & 0.0 & 13 & 9.9 \\
Small & 20 & 53.3 & 20 & 6.7 & 0.0 & 13 & 11.5 \\
Soppo & & & & & & & \\
Others & 0.0 & 0.0 & 0.0 & 0.0 & 100 & 10 & 7.6 \\
Mean & 28.5 & 33.9 & 18.3 & 8.3 & 11 & - & 100.0 \\
\hline Source: fild & (2.0 & & & & &
\end{tabular}

Source: field work (April 2013).

NB: The total is gotten by calculating the total number of responses from each neighborhood and dividing by the grand total of the respondents in the research as indicated on the table (131). While the total below is gotten by summing and then dividing the sum total of each variable by the total number of neighborhoods (10). The sum total of the mean results does not include the number of respondents (131).

Apparently, the right to water for everyone; to have a minimum quantity of water of good quality sufficient for life and health, regardless of economic activity or status, in this neighborhood is not attained (Tamasang, 2007). And so this concurs with (IFAD, 2012) that the bulk of the world's poor living in sub-Saharan Africa and South Asia are also the world's most water poor (Molden, 2007).

These water poor according to Molden (2007) also suffer from exploitation from the water companies and heads of Community Water Management Boards. During a focus group discussion, participants described the water situation in Buea as a nightmare. They further stated that in spite of this crisis, they still paid high water bills every month. "... CAMWATER is not reliable. Sometimes we stay for two months or more without water but they keep bringing high water bills... we are not sure they even take the meter reading..." commented one of the female participants. Women who have been relocated to a new market outside the Molyko neighbourhood complained of deception and similar exploitation from the municipal authorities. One woman (at this new market) referring to these authorities remarked that "...they merely deceived us to come here when they promised to provide us water. Immediately we came over, the market taps stopped flowing so that we must buy water to quench out thirst..." Other participants complained of the unfaithfulness of some quarter heads that collect money to install community public stand taps without doing so. "... No one seems to care about our situation..." was another common response from most of our respondents.

\subsection{Gender is Not a Consideration in the Allocation of Potable Water in the Municipality}

Although women may constitute the majority of those affected by the water crisis in Buea, gender considerations are not among the primary factors considered in the allocation of water facilities in the municipality. A compilation of the three main factors that determine stakeholders' choices in the allocation of water across neighbourhoods reveals that $57 \%$ of the stakeholders focus on the buying power of the population, $33 \%$ are influenced by the population density of the area and just $10 \%$ consider gender. Water provision in Buea is thus driven by its commoditization, rather than its social necessity as a basic human right. Groenewald (2012) indicates that the cost of getting quality water to households, industry and farmers in South Africa makes water a scarce and valuable commodity.

Strengthening the above assertion, interviews with the Chief of Service for CAMWATER in Buea indicated that water installation coverage in the area does not include small villages because, these villages cannot cover the cost of potable water supply. The villages consume community water that is communally managed. He noted that "...the population of the locality is very crucial when it comes to water management and development. The company is out to make profit and as such the market size is important as it will pay for the cost of operation. We believe that the small villages cannot pay for our connections because they are not financially viable." Cost and profit are increasingly seen as important variables in the provision of basic utilities. Banerjee et al., (2008) have argued that like any business, utilities must recover their costs if they are to sustain their operations. These 
authors and others dwell on the importance of tariff as a medium of sending price signals to users about the relationship between water use and water scarcity, and to ensure fairness in water service delivery (Cardone and Fonseca, 2003).

\subsection{The Effect of Water Crisis is Gender and Socially Differentiated in the Study Area}

The water crisis in Buea affects virtually every body, but not to the same degree. It has disrupted the activities of the poor, especially women and girls, more than those of men and the upper class in the community. Access to water is both a basic human right and essential for achieving gender equality (by freeing women and girls from spending long hours fetching water), sustainable development and poverty alleviation (Chipeta, 2009). This is still an unrealized dream for inhabitants of Buea. Table 3 presents respondents' perceptions of those they believe are affected by the water situation in Buea. The mean total of the responses shows that the poor, $(41.4 \%$, constitute the relative majority, followed by women (32.1\%). The variation of the responses across neighborhoods reflects the characteristics of the population of each neighborhood. As a result, a predominantly poor neighborhood like Great Soppo (made up of a women majority who are small food crop traders and housewives) naturally thought of themselves as badly affected. The same trend is noticed with the figure for affected women, which can be attributed to their domestic roles. As one female respondent puts it, "... a woman is the kitchen and therefore the house. She cannot be separated from water..." Regrettably, these poor cannot easily afford the funds to pay for water supply to their homes.

Table 3. Category of the population mostly affected by water crisis in Buea

\begin{tabular}{|c|c|c|c|c|c|c|c|}
\hline \multirow{2}{*}{ Location } & \multicolumn{6}{|l|}{ Responses } & \multirow{2}{*}{$\begin{array}{l}\text { Total } \\
\%\end{array}$} \\
\hline & $\begin{array}{l}\text { The } \\
\text { Poor \% }\end{array}$ & $\begin{array}{l}\text { The } \\
\text { Rich \% }\end{array}$ & $\begin{array}{c}\text { Men } \\
\%\end{array}$ & Women \% & Every-body \% & $\begin{array}{l}\text { Total No } \\
\text { Of } \\
\text { responders }\end{array}$ & \\
\hline Buea Town & 50 & 10 & 10 & 20 & 10 & 10 & 7.6 \\
\hline Small Soppo & 23.1 & 7.7 & 15.4 & 38.5 & 15.4 & 13 & 9.9 \\
\hline Bokwaongo & 40 & 20 & 20 & 20 & 00 & 10 & 7.6 \\
\hline Great Soppo & 53.3 & 00 & 6.7 & 33.3 & 6.7 & 15 & 11.5 \\
\hline Bonduma & 46.7 & 6.7 & 00 & 33.3 & 13.3 & 15 & 11.5 \\
\hline Molyko & 33.3 & 00 & 6.7 & 33.3 & 26.7 & 15 & 11.5 \\
\hline Bwitingi & 60 & 00 & 00 & 20 & 20 & 15 & 11.5 \\
\hline Muea & 30.8 & 00 & 00 & 46.2 & 23.1 & 13 & 9.9 \\
\hline Mile 16 & 26.7 & 00 & 00 & 66.7 & 6.7 & 15 & 11.5 \\
\hline Others & 50 & 10 & 10 & 10 & 20 & 10 & 7.6 \\
\hline Mean & 41.4 & 5.4 & 6.9 & 32.1 & 14.2 & - & 100 \\
\hline
\end{tabular}

Source: field work (April 2013).

Corroborating the above findings, (IFAD 2001a) adhere to the fact that most of the world's 1.2 billion poor people, two thirds of whom are women, live in water scarce countries. They do not have access to safe and reliable supplies of water for productive and domestic uses. As a result, women and children have to travel miles to fetch water. This explains Cleaver (1997) scowl on discrimination in resource management against main water users. Going by the UN, 2004 observation, safe drinking water is a basic human right and essential for achieving gender equality, sustainable development and poverty alleviation. It is therefore imperative to make available water points nearer the homestead to reduce the distance women and girls have to walk. When this happen, more time is gained for additional productive activities, including training, childcare, growing food and income generation.

\subsection{The Water Crisis Has Increased the Cost of Water Particularly for Women in the Municipality}

During water crisis periods, women still play a central role in the provision, management and preservation of water in Buea. To ensure the minimum amount of water for the household, $50 \%$ of the respondents report that they cover about $1 \mathrm{~km}$ to fetch water, $30 \%$ travel over $2.5 \mathrm{~km}$ and just $20 \%$ considered their distances to water sources as short or acceptable (Table 4). Besides these long and arduous distances covered to fetch water, inhabitants are still faced with the challenge of spending about1-2 hours on a queue to collect water at water points. Up to $50 \%$ of the respondents reported spending long hours tussling for water. This is because the public stand taps are few, and usually overcrowded, and the number of containers to be filled by each person is usually 
large. These distances, and hours spent, mean an increase in time cost especially for poor women with multiple roles. The economic cost is huge as revealed in a similar study by Fonjong (2004), in neighboring localities of Ekona and Muea, confirming the plight of women in traveling over long distances and spending hours in long queues to fetch water. That study further stresses that women operating under these conditions and without labor saving technologies at home cannot be very productive although they may fight to survive.

With regard to the financial incidence of the crisis on respondents, they were all unanimous that they spent a lot more to maintain other sources--springs, community water catchments or broken public stand taps. Nursing mothers and small businesswomen who require a lot of water attest to the fact that their water budgets have risen in some months by $30 \%$. Similar studies by Bosch et al, (2001) hold that the increasing water cost for many water poor who fetch water over long distances or who end up paying high prices to water vendors for very small quantities of water is backbreaking.

The right to water may not be enjoyed simply because there is sufficient, safe and acceptable water for domestic and personal use. The right to water makes sense where water and water services are accessible and affordable to everyone within acceptable distances and costs. Physical accessibility here is crucial because it has implications on water quality and cost. That is why water facilities and services should be provided within the immediate vicinity of households, educational institutions, workplace, or within the safe reach of the population. Collection of water from distant sources imports both direct and indirect risks to health. Women and children are most affected in this sense because they are the major collectors of water for domestic and personal use (Tamasang, 2007) and those who care for the sick when there is a water epidemic.

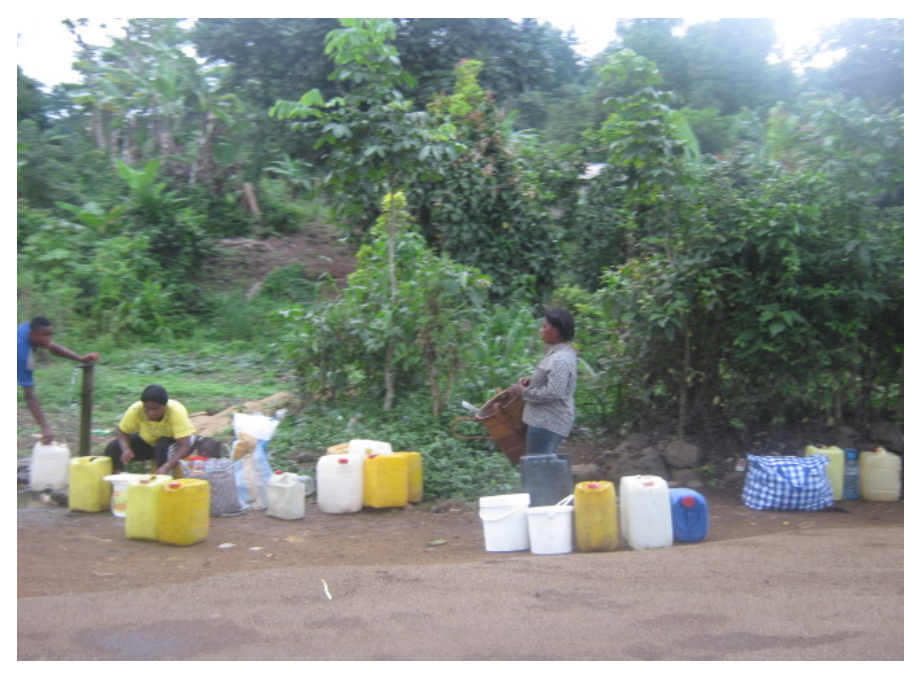

Figure 1. Women carrying water at Bwitingi community stand tap. The number of containers carried by each person explains the length of time spent at water points

Table 4. Cost of water collection reported by respondents in Buea

\begin{tabular}{|c|c|c|c|c|c|c|}
\hline \multirow[t]{2}{*}{$\begin{array}{l}\text { Distance } \\
\text { from source }\end{array}$} & \multirow{2}{*}{$\begin{array}{l}\text { Length covered } \\
\text { trekking per } \\
\text { hours }\end{array}$} & \multirow[t]{2}{*}{$\begin{array}{l}\text { Time spent at } \\
\text { water collection }\end{array}$} & \multirow[t]{2}{*}{$\begin{array}{l}\text { Number of } \\
\text { times per day }\end{array}$} & \multicolumn{2}{|c|}{$\begin{array}{l}\text { Amount of money spent } \\
\text { to fetch water }\end{array}$} & \multirow{2}{*}{$\begin{array}{l}\text { Percentage } \\
\%\end{array}$} \\
\hline & & & & Per week & Per month & \\
\hline $\begin{array}{l}\text { Short } \\
\text { distances }\end{array}$ & 15 minutes & $\begin{array}{l}30 \text { minutes to } 1 \\
\text { hour. }\end{array}$ & $\begin{array}{l}\text { three (3) } \\
\text { times per day }\end{array}$ & 500 & $4000 \mathrm{frs}$ & 20 \\
\hline $\begin{array}{l}\text { Middle } \\
\text { distances }\end{array}$ & 45 minutes & Time varies & $\begin{array}{l}\text { Two (2) } \\
\text { times a day }\end{array}$ & 2000 & $1000-5000 \mathrm{frs}$ & 50 \\
\hline $\begin{array}{l}\text { Long } \\
\text { distances }\end{array}$ & 1 hour and more & $\begin{array}{l}3 \text { hours ( } 4 \text { am }- \\
6: 30 \text { ap) }\end{array}$ & one time (1) & 10000 & 40000frs & 30 \\
\hline
\end{tabular}

Sources: field work (April 2013). 


\subsection{The Water Situation in Buea Has Effects on Women'S Socio-Economic Activities}

The effects of poor water provision go beyond time and money costs mentioned above to include indirectly, health and other opportunity costs. Water related diseases are among the most common diseases causing death in the developing countries (United Nations, 2004). The situation needs to be reversed in line with the Millennium Development Goals for 2015 by improving water access and quality in poor regions. Gleick (1998) suggests that water used for human consumption needs to be protected to potable water quality standards in order to eradicate water borne diseases. The damaging health effect of poor water consumption was recorded in the study area particularly in the Mile 16 neighborhood. Table 5 describes the outcome from a question in which the respondents were asked to state the likely effects of water contamination on their individual communities. It reveals that $75 \%$ of respondents from Mile 16 pointed at water contamination related ailments like cholera and stomach disorder and 25\% reported typhoid. Although there was no analysis of their medical reports to confirm these figures, they are nonetheless indicative of the importance of providing safe accessible and affordable water to the population. Studies by Fonjong (2008) confirm that water crisis are deadly and have cost the lives of children in the North West Region of Cameroon.

Economically, respondents indicated that they are restrained by water scarcity from operating their businesses regularly as reported by $21.3 \%$ in Bonduma and $10 \%$ in Bokwaongo. The effect on students was reported in the dominantly student resided neighborhood of Molyko (33.3\%). Some inhabitants of the town have also been forced to move from neighborhoods that suffer frequent water problems. For example, more people were reported to have moved or are moving from neighborhoods like Bokwaongo (20.8\%) and Buea Town (20.7\%) to others with less severe water situations. The disproportionate effect on women is indirectly reported by $19.7 \%$ who mentioned poor living conditions and 5.9\% on destruction of food crops. In the case of the former, girls and women are the main sufferers since they are those traditionally expected to spend energy, time and finances to care for those affected by poor living conditions. While for the latter, women make up the majority of those involved in food crop activities like the cultivation of vegetables in the area (Fonjong, 2004).

Table 5. Effect of water contamination on women's socio-economic activities

\begin{tabular}{lllllllll}
\hline Locality & \multicolumn{2}{l}{ Outcome of water contamination } & & & & \\
\cline { 2 - 9 } & Typhoid \% & $\begin{array}{l}\text { Cholera } \\
\text { and } \\
\text { stomach } \\
\text { disorder } \%\end{array}$ & Migration \% & $\begin{array}{l}\text { Poor } \\
\text { living } \\
\text { style \% }\end{array}$ & $\begin{array}{l}\text { restrain } \\
\text { on } \\
\text { business }\end{array}$ & $\begin{array}{l}\text { Negative } \\
\text { implication } \\
\text { on } \\
\text { education \% }\end{array}$ & $\begin{array}{l}\text { Destruction } \\
\text { of } \\
\text { crops } \%\end{array}$ & $\begin{array}{c}\text { Total\% } \\
\text { food }\end{array}$ \\
\hline Bokwaongo & 23.1 & 0.0 & 20.8 & 15.4 & 10 & 23 & 7.7 & 10.0 \\
Mile 16 & 25 & 75 & 0.0 & 0.0 & 00 & 0.0 & 0.0 & 10.0 \\
Bonduma & 16.7 & 0.0 & 10 & 25 & 21.3 & 8.3 & 16.7 & 9.8 \\
Buea Town & 12.3 & 0.0 & 20.7 & 21.4 & 14 & 28.6 & 0.0 & 9.7 \\
Bwitingi & 25 & 0.0 & 50.0 & 20 & 00 & 0.0 & 0.0 & 9.5 \\
Great Soppo & 20 & 0.0 & 23.3 & 10 & 13.3 & 20 & 13.3 & 10.0 \\
Molyko & 13.3 & 0.0 & 20.7 & 13.3 & 10 & 33.3 & 13.3 & 10.4 \\
Muea & 28.6 & 0.0 & 14.3 & 28.6 & 00 & 20 & 0.0 & 9.2 \\
Small Soppo & 0.0 & 0.0 & 30.8 & 30.1 & 13 & 15.4 & 7.7 & 9.7 \\
Others & 15.0 & 0.0 & 10.0 & 33.0 & 29.0 & 29.0 & 0.0 & 11.6 \\
Mean & 17.9 & 7.5 & 20.1 & 19.7 & 11.1 & 17.8 & 5.9 & 90 \\
\hline
\end{tabular}

Missing responses $=(0.1 \%)$.

Source: field work (April 2013).

Summing up these effects in a follow up discussion with participants in two focus groups, it was observed that women faced many health challenges due to poor sanitary conditions. Three of the participants $(16.7 \%)$ from Mile 16 neighbourhood stated that water contamination has led to the loss of lives from cholera and typhoid infections. Participants reported that they spent so much energy, time as well as finances nursing those affected by water contamination. Ten other participants $(55.6 \%)$ reported that water crisis has exposed women and particularly young girls to rape and sexual harassment "... the long and bushy paths are hideouts for rapists who sexually harass our young girls..." The participants also observe that the overcrowded nature of water points 
and tussling for water sometimes leave people with broken water containers and in some cases stolen containers. Nursing mothers also lamented because of the water crisis stating that huge sums of money are spent buying or paying people to fetch water.

Moreover, five participants (27.8\%) reported that they are unable to run their businesses smoothly because of the water crisis. As remarked by a hairdresser, "... we the hairdressers miss quick money when we do not have water to wash the hair of our clients..."

Food vendors on their part complained that they missed many customers when they cannot get to the market on time in periods of water crisis. The result is that they lose perishable food that cannot be sold. Considering the fact that women play the major roles in the home, especially in the areas of health and education, lack of water or the high cost of water presents very serious problems for grassroots women who have to pay for everything consumed in the household, including food, water and electricity. This demanding situation has left most female petty traders unable to satisfy both their increasing family responsibilities and save for business expansion hence, leaving them marginalized, Fonjong (2002).

These problems only go to confirm the UN's (2004) assertion that women and girls are those who always pay the price for water scarcity. It does require conscious policy moves and commitments to mainstream gender issues in water provision that will lead to equitable division of power, work, access to and control of resources between women and men. Such planning will ensure that the specific needs and concerns of women and men from all social groups are taken into account in development.

\section{Conclusions}

It is obvious that, water is indisputably a major feature for socio-economic development of the underprivileged women in Buea. Paradoxically, Buea which is well watered; and endowed with substantial rainfall and other natural water sources suffers from incredible water crisis. This study suggests that the water crisis in the municipality is a human creation and women suffer more than men because water is no longer considered a public but an economic good. The effect of this emerging status of water is that those whose activities are closely tied to water such as women in Buea pay the highest price for water in the form of time, money, health, and profit loss. The resulting situation has implications on the ability of women and the entire population to contribute to poverty alleviation and sustainable development. But since women are crucial in the economic life of Buea and other developing economies, water policies need to be engendered and women empowered to effectively participate in municipal water management. In fact, stakeholders involved in water provision, particularly public authorities should recognize the fact that water is a basic human rights and as such, it is the duty of the state to guarantee the availability and affordability of water to its population, This requires, among other things, a policy that ensures that population growth and the expansion of water infrastructures keep pace together.

\section{References}

Aureli, A., \& Brelet, C. (2004). Women and Water: an Ethical Issue. United Nations Educational, Scientific and Cultural Organization France, 4, 1-36

Banerjee, S., Foster, V., Ying, Y., Skilling, H., \& Wodon, Q. (2008).Cost recovery, equity, and efficiency in water tariffs: Evidence from African utilities. The World Bank USA, 1-52.

Bosch, C., Hommann, K., Rubio, M., Sadoff, C., \& Travers, L. (2001). Water, sanitation and poverty, 1-45.

Cardone, R., \& Fonseca, C. (2003). "Financing and Cost Recovery." Thematic Overview Paper IRC International Water and Sanitation Center, Delft, the Netherlands.

Chipeta, L. (2009). The water crisis in Blantyre city and its impact on women: The case of Mabyani and Ntopwa, Malawi, 10(4), 17-33.

Cleaver, F. (1997). Gender incentives and informal institutions: Women, men and the management of water, 43-64.

Epule, T. E., Changhui, P., Moto, W., \& Ndiva, M. (2011). Well water quality and public health implications: The case of four neighbourhoods of the city of Douala, Cameroon. Global Journal of Health Science, 3(2), 76. http://dx.doi.org/10.5539/gjhs.v3n2p75

Fonjong, L. (2002). Micro financial institutions as agents of improvement of women's economic position in North Western Cameroon. Atlantis, 26(2), 120-130.

Fonjong, L. (2004). Challenges and Coping Strategies of Women Food Crops Entrepreneurs in Fako Division, 
Cameroon. International Journal of Women's Studies, 5(5), 1-59.

Fonjong, L. (2008). Gender Roles and Practices in Natural Resource Management in the North West Province of Cameroon. Local Environment, 13(5), 461-475. http://dx.doi.org/10.1080/13549830701809809

Fonjong, L., Ngwa, E., \& Fonchingong, C. (2004). Rethinking the Contribution of Indigenous Management in Small-Scale Water Provision Among Selected Rural Communities in Cameroon. Environment, Development and Sustainability, 6, 429-451. http://dx.doi.org/10.1007/s10668-005-0501-3

Gleick, H. P. (1998). Water in crisis: paths to sustainable water use. The Ecological Society of America, 571-579.

Groenewald, Y. (2012). Coal's hidden water cost to South Africa. Greenpeace Africa, 1-12. Retrieved from http://www.greenpeace.org/africa/Global/africa/publications/coal/CoalsHiddenWaterCost

IFAD, (2001a). Rural Poverty Report 2001. The challenges of ending rural poverty. Oxford University Press. IFAD, Rome. Retrieved from http://www.ifad.org/poverty/ch.cont

IFAD, (2012). Securing water for improved rural livelihoods: The multiple-uses system approach. IFAD, Rome. R. Cleveringa \& A. Lubbock.

MDG, (2006). Meeting the MDG Drinking Water and Sanitation the Urban and Rural Challenge of the Decade. World Health Organization and UNICEF Switzerland, 1-47.

Molden, D. (Ed.) (2007). Water for food, water for life: A comprehensive assessment of water management in agriculture. London: Earths can; Colombo, Sri Lanka: International Water Management Institute. Retrieved from http://www.iwmi.cgiar.org/assessment/index.htm

Muta'a Hellandendu, J. (2012). Health Implications of Water Scarcity in Nigeria. Zaria, 8(18), 1-7.

Tamasang, C. F. (2007). The Right to Water in Cameroon: Legal Framework for Sustainable Utilisation. Swiss National Science Foundation (SNF), 1-22.

UN. (2004). A Gender Perspective on Water Resources and Sanitation, New York, 1-25. Retrieved from http://www.un.org/esa/sustdev/csd/csd13/documents/bground_2

UN. (2005). Women 2000 and Beyond: Women and Water. United Nation, New York, 1-28. Retrieved from http://www.un.org/womenwatch/daw/public/Feb05

Yongsi, H. B. N. (2010). Suffering for Water, Suffering from Water: Access to Drinking-Water and Associated Health Risks in Cameroon International Centre for Diarrhea. Canada, 424-435.

\section{Copyrights}

Copyright for this article is retained by the author(s), with first publication rights granted to the journal.

This is an open-access article distributed under the terms and conditions of the Creative Commons Attribution license (http://creativecommons.org/licenses/by/3.0/). 